\section{Perception of Carbon Dioxide and Other "Air-Condition" Parameters in the Leaf Cutting ant Atta cephalotes}

\author{
C. Kleineidam, J. Tautz \\ Theodor-Boveri-Institut, Lehrstuhl für Verhaltensphysiologie und Soziobiologie, \\ Universität Würzburg, D-97074 Würzburg, Germany
}

Social insects often build subterranean nests to protect themselves and their brood from predators and environmental influences. These nests can reach remarkable sizes, covering an area of up to $40 \mathrm{~m}^{2}$ and reaching $6 \mathrm{~m}$ below the surface [1]. The fungus gardening leaf cutting ants (genus Atta) have special demands for their nests, including stable microclimatic conditions required by the fungus. The climatic parameters, such as humidity, temperature, and the concentration of $\mathrm{CO}_{2}$, have direct impact on the development of the brood and on the fitness of the whole colony [2]. The ants appear to be able to regulate these conditions by constructing and, when needed, altering ventilation channels, which are an important part of the nest [3].

Various types of sensilla, often hairshaped sensory organs with up to 30 receptor neurons densely cover the antennae and perceive chemical and mechanical stimuli. In $A$. cephalotes there are about 1400 sensilla on each antenna, and thus an enormous number of sensory cells relay the information to the brain [4]. In addition to pheromones, food odors, and mechanical stimuli, changes in environmental parameters are detected by antennal sensilla.
Much work has been carried out to classify the different morphological types of antennal sensilla, mainly for phylogenetic studies [5]. In ants, however, little is known about the physiology of most types of sensilla $[6,7,8]$. Furthermore, in insects the morphological characteristics of sensilla do not necessarily reveal their specific stimulus modality, for example, hygroreceptors have been identified in sensilla basiconica of the moth [9] and in sensilla coelocapitula of the honey bee [10]. In order to understand the biological role of the antennal receptors we first identified the adequate stimulus modalities of different types of sensilla in $A$. cephalotes by extracellulary recording the activity of their receptor cells. The technique was similar to that described by Masson and Friggi [7], except that the indifferent electrode was placed in a different position, to avoid recording of muscle activity, which otherwise could easily be mistaken for sensory activity. The recording electrode was either an electrolytically sharpened tungsten wire or, for tip-recording [11], a glass electrode was used. Signal amplitudes were in the range of $0.1-0.6 \mathrm{mV}$ (bandpass filtered between $60 \mathrm{~Hz}$ and $2 \mathrm{kHz}$ ). None of the hair- shaped sensilla responded to changes in temperature and humidity or to $\mathrm{CO}_{2}$ stimuli. Sensory cells of the sensilla trichodea curvata responded to the alarm pheromon 4-methyl-3-heptanon. The sensilla basiconica carry contact chemoreceptors reacting to various salt solutions while the sensilla chaetica, which we always found associated with one particular type of sensilla basiconica, have mechanoreceptors.

In a distinct area of the last flagellar segment small holes are detectable. These are apertures of two other types of sensilla situated below the surface of the cuticle. Depending on their shape they are called sensilla coeloconica or sensilla ampullacea. They are common in the hymenoptera and were first described by Forel in 1884 but he was unable to suggest an adequate stimulus modality for these morphological types [12]. In both cases a peglike structure is located in a cavity with only a small aperture to the outside. The sensillum coeloconicum resides completely within the thick antennal cuticle (Fig. 1 b). In contrast, the sensillum ampullaceum extends further into the lumen of the antenna (Fig. 1 a). Concentrated in an elliptic array on the ventrolateral side of the last flagellar segment, the sensilla coeloconica are situated distally, and the group of $10-12$ sensilla ampullacea are proximal to them.

Both types of sensilla are associated with a temperature receptor which is either excited (warm receptor) or inhibited (cold receptor) by increasing temperature. In the distal part of this sensilla arrangement recordings of cold receptors are possible, demonstrating association of these receptors to sensilla coeloconica. In contrast, warm receptors are found in the proximal part. In two experiments we have shown that a 


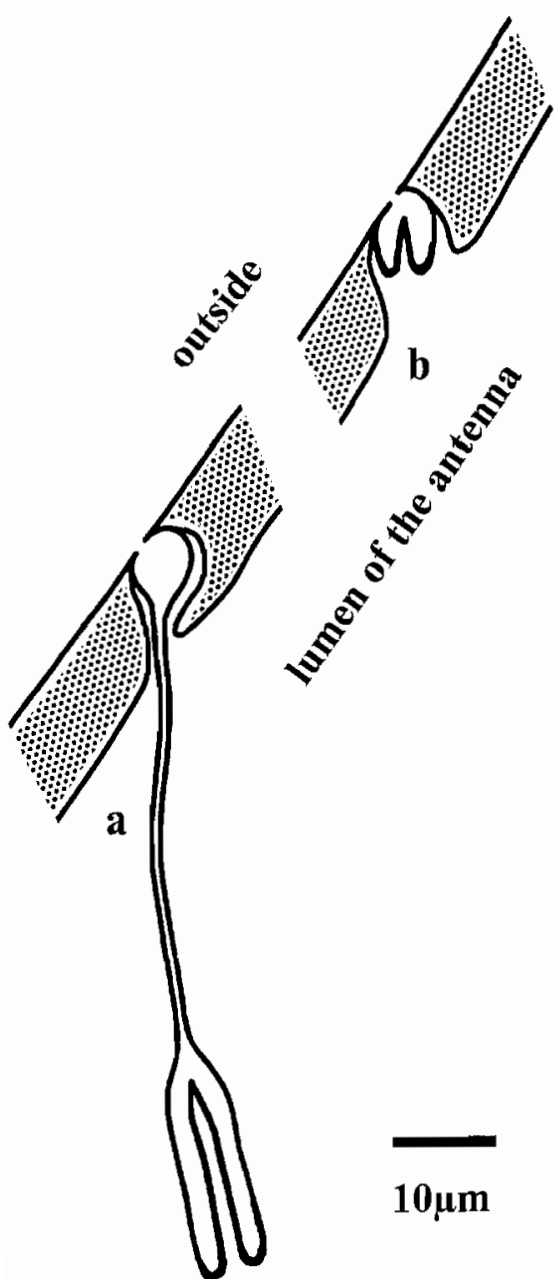

Fig. 1. Sensillum ampullaceum (a) and sensillum coeloconicum (b), schematized from semithin sections of the antenna. Scale bar: $10 \mu \mathrm{m}$

warm receptor sensory neuron is associated together with a $\mathrm{CO}_{2}$-receptive cell within the same sensillum ampullaceum (identification, see below). The response of the temperature receptors is phasic-tonic, with a resolution of at least $0.2^{\circ} \mathrm{C}$. This accords with behavioral studies of temperature sensitivity in ants [13].

Scanning electron microscopy from the interior of the antenna reveals the extraordinary structure of the sensillum ampullaceum (cover foto). An ampulla, deeply invaginated into the lumen, is connected to a cavity within the thick antennal cuticle by a long and narrow duct (diameter $1.5 \mu \mathrm{m}$; Fig. 1 a). The length of the ducts varies from 20 to $50 \mu \mathrm{m}$ in $A$. cephalotes (in a single individuum) and even more obvious length variations occur between differ-

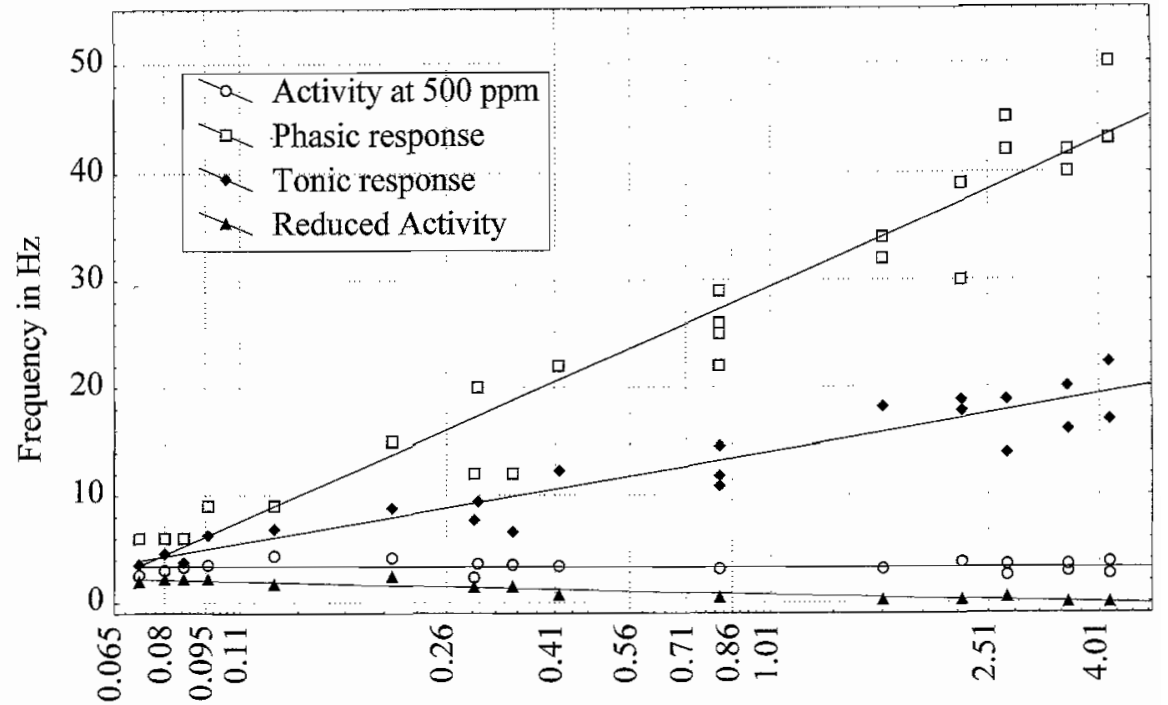

Concentration of Carbon Dioxide in \%

Fig. 2. Threshold curve of $\mathrm{CO}_{2}$ receptors. Neuronal activity vs. stimulus intensities, ranging from $0.02 \%$ to $4 \% \mathrm{CO}_{2}$ added to a continuous air flow of $0.05 \% \mathrm{CO}_{2}$. Raw data from three different receptor cells

ent ant subfamilies (Ponerinae and Formicinae [5]).

We have identified the sensilla ampullacea as $\mathrm{CO}_{2}$ receptors. After recording action potentials in response to $\mathrm{CO}_{2}$ the sensillum was identified by staining with DiI. The lipophilic dye was applied with a glass capillary put onto the aperture of the recorded sensillum. Sectioning afterwards revealed that only a single sensillum of the group was stained. We investigated the stimulus coding properties of the $\mathrm{CO}_{2}$ receptor cells innervating the sensilla ampullacea in greater detail. The $\mathrm{CO}_{2}$ stimulus was applied by an injection of $\mathrm{CO}_{2}\left(10 \%\right.$ in $\mathrm{N}_{2}$ or $\left.100 \% \mathrm{CO}_{2}\right)$ into a continuous air flow $\left(0.05 \% \mathrm{CO}_{2}, 21 \%\right.$ $\mathrm{O}_{2}, 78.95 \% \mathrm{~N}_{2}$ ) directed onto the tip of the antenna. The injection of $\mathrm{CO}_{2}$ was controlled by a magnetic valve. At $500 \mathrm{ppm} \quad \mathrm{CO}_{2}$ concentration (atmospheric concentration $\sim 300 \mathrm{ppm}$ ) the frequency of action potentials of the receptor cell is about $4 \mathrm{~Hz}$. With increasing concentration an initial phasic response with a duration of approximately $1 \mathrm{~s}$ is followed by a tonic plateau. After termination of the stimulus the activity is reduced, for a period the length of which depends on the intensity of the preceding stimulus. A plot of the mean response frequency vs. stimulus intensities reveals that the phasic and the tonic components do not saturate in the tested intensity range (0.05-4\%; Fig. 2).

The threshold curves in Fig. 2 represent raw data from three different receptor cells. The response characteristics of nine other cells in which fewer stimulus intensities were tested, match the curve in Fig. 2 very well. Thus our data indicate that most of the $\mathrm{CO}_{2}$ receptors work in the same sensitivity range. The $\mathrm{CO}_{2}$ receptors found in honey bees vary in their sensitivity but have not been identified any further [14]. In addition to the sensilla ampullacea, honey bees have two more types of sensilla below the surface of the flagellum [15]. Normally the half-maximal response is used to compare the sensitivity of receptors, but we did not test stimulus intensities close to saturation. In some lepidopteran species that use $\mathrm{CO}_{2}$ to locate oviposition sites the half-maximal response occurs at stimulus intensities as low as $75 \mathrm{ppm}$ [16], which is only about $10 \%$ of the lowest intensity tested in this study.

The various components (phasic, tonic, rebound) of the sensory response code different aspects of the stimulus. The level of $\mathrm{CO}_{2}$ concentration is best represented by the tonic part of the response, which shows no adaptation even after a stimulus of $10 \mathrm{~min}$ (stimulus intensity of $0.82 \%$ ). This receptor serves as a logarithmic measuring system in a wide range of intensities and should enable the leaf cutting ant to monitor the current $\mathrm{CO}_{2}$ concentration continuously in the chambers of their 
nest. Due to its initial phasic response component the receptor should be able to assess, in addition to the absolute $\mathrm{CO}_{2}$ concentration, also the time course of increasing $\mathrm{CO}_{2}$ concentration. A spatial gradient in $\mathrm{CO}_{2}$ concentration could be perceived by antennal scanning movements. Inside the nest such gradients may be caused by increased activity of the fungus and ants in the chambers. Outside gradients exist due to sources and sinks of $\mathrm{CO}_{2}$ [17]. For instance, the nest entrance acts as a large $\mathrm{CO}_{2}$ source and may establish a gradient which expands near the ground much further than in turbulent air. Orientation to an odor gradient in the laminar boundary layer close to the surface may be possible for ants because mass transport here obeys only the law of diffusion [18]. The initial phasic compound and the rebound characteristics of their $\mathrm{CO}_{2}$ receptors and the additional fast sampling of different levels in the boundary layer may enhance the resolution of small vertical gradients. Indeed, it has been estab- lished that ants use $\mathrm{CO}_{2}$ as a cue to find the entrance of their nest [19].

We thank W. Gronenberg for his experimental support and critical reading the manuscript and B. Hölldobler for helpful discussion. Financial supported by funds of the Deutsche Forschungsgemeinschaft (SFB 251 and Graduiertenkolleg „Grundlagen des Arthropodenverhaltens").

1. Hölldobler B, Wilson, E.O.: The Ants. Belknap, Cambridge 1990

2. Roces, F.: J. Comp. Physiol. A 177, 637 (1995)

3. Weber, N.A.: Gardening Ants: The Attines. American Philosophical Society, Philadelphia 1972

4. Schlumberger, A.: Thesis. University of Würzburg (1993)

5. Hashimoto, Y.: Japan Journal of Ent. 59(1), 125 (1991)

6. Dumpert, K.: Z. Vgl. Physiol. 76, 403 (1972)

7. Masson, C., Friggi, A.: J. Insect Physiol. 20, 763 (1974)

8. Masson, C., Friggi, A.: Comtes rendus. No 272, series D, 2346. Acad. Sc., Paris 1971
9. Dethier, V.G., Schoonhoven, L. M.: J. Insect Physiol. 14, 1049 (1968)

10. Yokohari, F., Tominaga, Y., Tateda, H.: Cell Tissue Res. 226, 63 (1982)

11. Kaissling, K.E.: Biochemistry of Sensory Functions, 243 (L. Jaenicke ed.) 1974

12. Forel, A.: Übrigens gestehe ich, daß man allerdings nur schwer versteht, wie Organe als Sinnesorgane funktionieren können, die in die Tiefe versenkt sind und mit der Außenluft nur durch ein dünnes Luftfädchen in Verbindung stehen. Wenn ihre Funktion also eine sensorielle sein sollte, so ist doch sicher, daß sie weder in die Sphäre des Geruchs noch des Geschmacks fällt. In: Das Sinnesleben der Insekten, 80 (1910) und Études myrmécologiques. Bull. Soc. Vaud. Sc. Nat. 20.91 (1884)

13. Herter, K.: Z. Vg1. Physiol. 2, 226 (1925)

14. Lacher, F.: Z. Vgl. Physiol. 48, 587 (1964)

15. Yokohari, F., Tominaga, Y., Tateda, H.: Cell Tissue Res. 226, 63 (1982)

16. Stange, G., Monro, J., Stowe, S., Osmond C. B.: Oecologica 102, 341 (1995)

17. Stange, G.: J. Comp. Physiol. A 171, 317 (1992)

18. Howse, P.E.: Experientia Supplementum 54, 271 (1.987)

19. Lechner, M.: 15 th dt. IUSSI Utrecht, 123 (1995) 